\title{
The Concept of Matrimonial Consent in Can. 1057 CIC 1983
}

\section{WOJCIECH WĄSIK}

The John Paul II Catholic University of Lublin wwasik@kielce.opoka.org.pl, ORCID: 0000-0001-9443-3429

\begin{abstract}
The article is devoted to matrimonial consent as described in Can. $1057 \mathrm{CIC} / 83$, which has replaced the former Can. $1081 \mathrm{CIC} / 17$. The regulation found in this canon emphasizes the importance of matrimonial consent and constitutes the basis for all reasons for the nullification of marriage. The analyzed norm, describing matrimonial consent in the positive aspect, was formulated in the personalistic spirit and adapted to Vatican Il's teachings. Can. $1057 \mathrm{CIC} / 83$ was placed among the norms introducing the De matrimonio of $\mathrm{CIC} / 83$ part, which resulted in ordering the vision of marriage in $\mathrm{ClC} / 83$. The studies on the normative content of Can. $1057 \S 1, \mathrm{ClC} / 83$, focus on matrimonial consent, which establishes the matrimonial bond and is the only efficient cause of marriage, being a bilateral consensual contract and a sacrament for those baptized. The article discusses legal requirements assuring that consent will result in contracting a valid marriage. The article explains in detail the norm, according to which a defective matrimonial consent cannot be supplemented or replaced by another legal act. The article analyses the object of matrimonial consent in Can. 1057 \$2, CIC/83, which was harmonized with the definition of marriage in Can. $1055 \mathrm{CIC} / 83$. Ius in corpus is no longer such an object (as it narrows marriage to a communion finding fulfillment in the sexual and procreative sphere) but rather the parties to the contract, who give themselves to one another in an analogous sense (material object) and the communion for their entire life, in all its dimensions (formal object).
\end{abstract}

Keywords: marriage, matrimonial consent, object of matrimonial consent, consensual contract, sacrament of marriage

Considering the need to adapt the legal norms to the contemporary realities of life and to the teachings on the subject of marriage developed by Vaticanum II, as well as the postulates put forward by jurisprudence, the church legislator introduced a revised norm on matrimonial consent to $C I C / 83^{1}$ - Can. $1057 \mathrm{CIC} / 83$, which replaced the former Can. $1081 \mathrm{CIC} / 17,{ }^{2}$ containing the definition of matrimonial consent as the efficient cause of marriage and a vague, narrow, even "physiological" definition of consent, ${ }^{3}$ which was the result of capturing the formal subject of matrimonial consent based on the primary purpose of marriage. ${ }^{4}$

1 Cf. Żurowski, Kanoniczne prawo, 75; Góralski, Małżeństwo kanoniczne, 43; Chiappetta, Il Codice, 266-267; Góralski et al., Komentarz do Kodeksu, 253-254.

2 Cf. Lüdicke, "Kryteria rozróżnienia," 61-62; Hemperek et al., Komentarz do Kodeksu, 214; Rybczyk, "Projekt reformy," 204.

3 Cf. Żurowski, Kanoniczne prawo, 79-80; Chiappetta, Il Codice, 267.

4 Cf. Pastwa, Istotne elementy, 111-112. 


\section{The Position and Significance of Can. 1057 in CIC/83}

When comparing the old and the new code, there is a noticeable difference in the location of the norm on matrimonial consent. ${ }^{5} \mathrm{Can} .1081 \mathrm{CIC} / 17$ was placed at the initial position of the chapter De consensu matrimoniali, opening a series of provisions on the defects of matrimonial consent. ${ }^{6}$ Thereby, in Can. 1081, $\$ 2$ CIC/17, the legislator defined matrimonial consent from the positive side, and in the following canons, they described this consent from the negative side. ${ }^{7}$ Can. 1057 CIC/83 was placed among the canons introducing the title VII De matrimonio, of book IV. De Ecclesiaemunere sanctificandi, right after Can. 1055 CIC/83, defining marriage, and Can. 1056 $\mathrm{CIC} / 83$, concerning the essential properties of marriage. These three canons constitute the structured vision of marriage in the Code. ${ }^{8}$ The change in the placement of the provision on matrimonial consent itself was a well-thought-out move, resulting in a more logical arrangement of the norms and an emphasis on the extraordinary importance of this regulation in the entire marriage law. The legislator also elected to omit the negative description of matrimonial consent, defining it in a positive aspect only. ${ }^{9}$

Can. 1057, \$2 CIC/83 is of exceptional importance in the entire system of canon law, because it constitutes the measure of the validity of the act of matrimonial consent. From the provisions contained in this norm, it is possible to derive all grounds for the invalidity of marriage; however, it cannot be ascertained when a marriage is invalid, ${ }^{10}$ with one exception: if the efficient cause of marriage is absent, i.e., matrimonial consent. Without doubt, a valid marriage cannot come to being in such a situation. The basis for the invalidity of marriage is a special form of simulation, which Bruno Primetshofer calls negative Totalsimulation, and Hermann Kahler - absentia consensus. In such a case, the marriage is invalid, not under Can. 1101, \$2 CIC/83 but pursuant to Can. $1057 \mathrm{CIC} / 83 .{ }^{11}$

5 Cf. Lüdicke, "Kryteria rozróżnienia," 61-62; Hemperek et al., Komentarz do Kodeksu, 214; Rybczyk, "Projekt reformy," 204.

6 Cf. Urbanowska-Wójcińska, “Zgoda małżeńska," 60.

7 Cf. Lüdicke, "Kryteria rozróżnienia," 61-62.

8 Cf. Erlebach, "Problem wymiaru," 14.

9 Cf. Comm. 9/1 (1977) 119-120; Lüdicke, "Kryteria rozróżnienia," 61-62; Urbanowska-Wójcińska, "Zgoda małżeńska," 60.

10 Cf. Lüdicke, "Kryteria rozróżnienia," 62; Reinhardt, "Nowe tendencje," 97.

11 Cf. Kahler, Absentia consensus, 29-362; Reinhardt, "Nowe tendencje," 98-101; Primetshofer, "Der Ehekonsens," 773; Wąsik, "Symulacja zgody," 250-251. 


\section{The Sources of Can. 1057 CIC/83}

The sources of Can. 1057, $\$ 1 C I C / 83$ can be divided into three groups: The first group includes Can. 1081, $\$ 1 \mathrm{CIC/17}$ and the encyclical Castii connubii, containing and re-announcing a comprehensive interpretation of the Catholic teaching on marriage. ${ }^{12}$ The second group consists of the Constitution Gaudium et spes of the Second Vatican Council. ${ }^{13}$ The third group includes the Allocution of Paul VI of February 9, $1976,{ }^{14}$ in which the Pope reminded that the efficient cause of marriage is matrimonial consent, not love. ${ }^{15}$

Reading Can. 1057, \$1 CIC/83 literally, it seems that the legislator omitted the teachings of Vaticanum II on matrimonial consent and made concessions to the conservative doctrine, repeating verbatim the contents of Can. 1081, $\$ 1 \mathrm{CIC} / 17 .^{16}$ It is only in the context of the sources that it becomes apparent that the normative content contained in the analyzed canon should be read in a new, personalistic approach. The consequence of this is the necessity to use such an interpretation of the norm in question that would take into account both the teachings of Vaticanum II and the post-conciliar doctrine ${ }^{17}$.

Among the sources of Can. 1057, \$2 CIC/83 are the former Can. 1081, 22 CIC/17 and Paul VI's Encyclical Humanae Vitae of July 25, 1968, ${ }^{18}$ in which the concept of the object matrimonial consent was extended. ${ }^{19}$

\section{The Efficient Cause of Marriage}

At the beginning of Can. 1057, $\$ 1 C I C / 83$, the legislator inscribed the legal principle of matrimonium facit partium consensus, ${ }^{20}$ which is rooted in natural law and confirmed by the Church's Magisterium. According to this principle, matrimonial consent is the element that causes the establishment of, or creates (facit), marriage, forming the marital bond. ${ }^{21}$ The principle itself is based on Ulpian's legal maxim,

\footnotetext{
12 Cf. CICFontes/83, 292; Skrzydlewski, "Castii Connubii," 1359-1360.

13 Cf. CICFontes/83, 292; Florczyk - Misztal, "Wprowadzenie do Konstytucji," 511.

14 Cf. CICFontes/83, 292.

15 Cf. Paulus VI, "Allocutio," 204-208; Navarrete, "Amor coniugalis," 619-632.

16 Cf. Pastwa, Istotne elementy, 125.

17 Cf. Stasiak, "Teologiczne podstawy," 83-84.

18 Cf. CICFontes/83, 292.

19 Cf. Navarrete, "Mutationes et praevisae," 4.

20 Cf. Chiappetta, Il Codice, 266-267; Bonnet, Introduzione al consenso, 3; Supremum Tribunal Signaturae Apostolicae, "Dioecesis Ultraiecten," 301; DS 643; DS 775; DS 756; DS 1327; DS 1497; DS 1813; DS 3713; DS 3701.

21 Cf. Hendriks, Diritto matrimoniale, 34; Majer, Kodeks Prawa, 782; Giacchi, Il consenso, 23.
} 
derived from Roman law, contained in the Digest: nuptias ... consensus facit, ${ }^{22}$ or on its later, Christian interpolation. ${ }^{23}$

In the analyzed norm, the concept of consensual contract was adopted as binding in the matter of the relevance and sufficiency of a matrimonial consent for marriage, instead of the concept of real contract, according to which marriage arises through the mutual transfer of rights to each other, i.e., through the act of marital intercourse. ${ }^{24}$ This is an important remark, because in the Code of John Paul II the concept of real contract was not completely rejected, as evidenced by Can. 1141 CIC/83 and Can. $1142 \mathrm{CIC} / 83 .{ }^{25}$

Matrimonial consent, as the efficient cause of marriage, according to Can. 1057, $\$ 1 \mathrm{CIC} / 83$, should not be equated with casualitas matrimonii in abstracto, or casualitas matrimonii divina, i.e., with the efficient cause of the essence of marriage, but with the efficient cause of the existence of a specific marriage, between a specific man and woman, i.e., with causalitas matrimonii humana. ${ }^{26}$ It should be added that marriage should be understood here in accordance with its definition contained in Can. 1055, $\$ 1 \mathrm{CIC} / 83,{ }^{27}$ primarily as foedus - covenant. This technical term borrowed from biblical terminology, found in the text of the constitution Gaudium et Spes, No. 48, faithfully reflects the complexity of the concept of marriage and, moreover, refers to the idea of contract. ${ }^{28}$ Formulated by Baldus de Ubaldis and based on the commentary to the Digest (D. 2.14), the rule states that contractus essentialiter regulantur a consensu duorum - each contract is regulated by the consent of the two parties, including its essence ("core of the contract"). ${ }^{29}$ Since marriage is a bilateral consensual contract, therefore, as with any contract, in order to come into being it requires agreement between the two parties- in this case, one man and one woman. A marriage contract becomes legally effective as a solo consensu, which means that apart from the declarations of will of the prospective spouses, no additional element is needed. Matrimonial consent plays the role of the efficient cause (causa efficiens) of marriage and the formal cause (causa formalis) of the marriage contract, constituting its internal structure. ${ }^{30}$ Ulpianus libro 36 ad Sabinum: Nuptias non concubitus, sed consensus facit; Mosiek, Kirchliches Eherecht, 194. 
The canonical marriage of the baptized described in Can. 1055 CIC/83 assumes a juridical-religious structure in such a way that it is impossible to separate marriage as a non-religious contract from marriage as a sacrament. ${ }^{31}$ In canon law studies, a question is asked as to whether the adoption of the solus consensus principle - whereby the efficient cause of marriage is only matrimonial consent - trivializes or even veils the sacramentality of marriage, because this principle was adopted from Roman law into the system of church law in different times, in a climate of a different legal culture, different ecclesial vision of marriage and not yet specified concept of its sacramentality. Moreover, the concept of marriage as "sacramentum naturae" and "sacramentum gratiae" should not be mixed. ${ }^{32}$ Attempts are being made to resolve this problem. Ulrich Rhode notes that the relationship between matrimonial consent and marriage is based on natural law. As a result, matrimonial consent as causa efficiens applies to all marriages, both those concluded according to natural law and sacramental ones. ${ }^{33}$ According to Otto Pesch, the teachings of the Church on the sacramentality of marriage require matrimonial consent according to Can. 1057, $\$ 2 C I C / 83$, which is a necessary condition for concluding marriage. Marriage, on the other hand, becomes a sacrament through the expression of consent among the baptized, which takes place in the Church. ${ }^{34}$ Augusto Sarmiento states that the sacramental sign is constituted by mutual matrimonial consent, which is elevated to the dignity of an effective sign of grace among the baptized. Inseparability exists between consent and the sacramental sign. However, this is only the case in marriages contracted between baptized persons. On the other hand, in the case of the unbaptized, a distinction must be made between sacrament and consent, which is the efficient cause of true marriage, but which is concluded only at the level of natural law. ${ }^{35}$. Orio Giachhi takes the position that, in the case of baptized persons, the contractual nature of marriage and its sacramentality are intertwined with each other, in the sense that the consent of the spouses, as an essential element of the contract, is also an essential element of the sacrament since the spouses themselves are ministers of this sacrament and jurisdiction of the Church over marriage is not limited to its sacramental aspect, but also influences its contractual aspect, which determines the conditions for the validity of this act. ${ }^{36}$ The legislator themselves in Can. 1055, $\$ 2$ CIC/83 declares that: a valid matrimonial contract cannot exist between the baptized without it being by that fact a sacrament. The sacramental profile of the Christian marriage is not something incidental, some external addition and supplement

\footnotetext{
31 Cf. Serrano Ruiz et al., Matrimonio canonico, 41ff; Wąsik, "Pojęcie małżeństwa," 200.

32 Cf. Zubert, "Consensus sacramentalis," 12-13.

33 Cf. Rhode, Vorlesung, 49.

34 Cf. Pesch, Ehe im Blick, 2, 13.

35 Cf. Sarmiento, Małżeństwo chrześcijańskie, 165

36 Cf. Giacchi, Il consenso, 24.
} 
to the marriage contract, but is part of the essence of the marital bond itself. ${ }^{37}$ Therefore, the doctrine of marriage in terms of contract and sacrament is inseparable, and its rejection would entail a rejection of the teachings of the Church's Magisterium. ${ }^{38}$ This means that qualified consent in the case of baptized spouses is simultaneously the efficient cause of the contract and the sacrament of marriage. ${ }^{39}$

The transfer of matrimonial consent may only be executed by those legally capable of contracting marriage, as expressed in Can. 1057, \$1 CIC/83 with the formula inter personas iure habiles. Consent cannot cause marriage to come to being in the event of the legal incapacity of one or both parties. This inability may be derived from God's natural or positive law, or from ecclesiastical law. ${ }^{40}$ From the declaration of natural law in Can. 1055, $\$ 1$ CIC/83 it follows that marriage may be contracted only by one man and one woman. ${ }^{41}$ There must be gender differentiation between the prospective spouses. Marriage cannot be a relationship between persons of the same sex, ${ }^{42}$ or with a person who has performed a "sex change", because such an operation only concerns the phenotype and does not change the genotype, i.e., the essence of a person's sex. ${ }^{43}$

The proper expression of matrimonial consent presupposes the proper functioning of the mind (cf. Can. $1095 \mathrm{CIC/83}$ ) and the will of the prospective spouses. The defects of consent relating to the will may concern a substantive difference between the act of the will and the meaning of its declaration (cf. Can. 1096-1097 CIC/83 and Can. 1099-1102 CIC/83) or a qualitative difference (cf. Can. 1098 CIC/83 and Can. $1103 \mathrm{CIC} / 83) .{ }^{44}$ Furthermore, impediments to marriage result in rendering the marriage null and void, unless a competent ecclesiastical authority has granted the required dispensation. ${ }^{45}$ In addition, spouses must be physically capable of entering into a valid marriage ${ }^{46}$; an example is the impediment of instrumental impotence, i.e., the inability to perform sexual intercourse, which results from the anatomical deficiencies of the genital organs. ${ }^{47}$

Can. 1057, $\$ 1 C I C / 83$ requires that the consent be externalized in accordance with the provisions of law - legitimae manifestatus. The manner of communicating

\footnotetext{
37 Cf. Vitali - Berlingò, Il matrimonio canonico, 9.

38 Cf. Aubé - Caparros, Code de droit, 916; Chiappetta, Il Codice, 267; Boggiano Pico, Il matrimonio, 297; Pawluk, Prawo Kanoniczne, 25-27; Giacchi, Il consenso, 24; Fumagalli Carulli, Intelletto e volontà, 45.

39 Cf. Gerosa, Prawo Kościoła, 281.

40 Cf. Góralski, Małżeństwo kanoniczne, 45; Żurowski, Kanoniczne prawo, 78.

41 Cf. Fernández Castaño, Legislación matrimonial, 106-107; Żurowski, Kanoniczne prawo, 78; Gerosa, Prawo Kościoła, 281.

42 Cf. Żurowski, Kanoniczne prawo, 78.

43 Cf. Stawniak, Niemoc płciowa, 322.

44 Cf. Lüdicke, "Kryteria rozróżnienia," 63.

45 Cf. Sztafrowski, Podręcznik prawa, 29-30; Gajda, Prawo małżeńskie, 39-40.

46 Cf. Duda, Katolícke manželské, 46; Fumagalli Carulli, Intelletto e volontà, 28.

47 Cf. Majer, Kodeks Prawa, 801; Stawniak, Niemoc płciowa, 184-194, 326-337.
} 
the matrimonial consent is specified in Can. 1104-1106 CIC/83. It should be expressed either by the prospective spouses simultaneously present or by a proxy duly appointed in accordance with law. It is to be conveyed in words or with equivalent signs. Using the assistance of an interpreter is allowed. On the other hand, the canonical form, i.e., persons to whom such consent is expressed, is specified in Can. 1108 CIC/83 and Art. 6 Motu Proprio of Pope Francis De concordia inter Codices, of May 31, 2016 (ordinary form) and Can. 1116 CIC/83 and Art. 10 Motu Proprio De concordia inter Codices (extraordinary form). ${ }^{48}$

Can. 1057, \$1 CIC/83 also contains the rule according to which the matrimonial consent expressed by the prospective spouses may not be supplemented by any human authority. This means that if the consent is deficient or defective, it cannot be replaced by any other legal act. This cannot be completed either by a later coexistence, or by long-term cohabitation, or by an act of will expressed through a third party (e.g., parents), nor can it be done by any human legal authority. ${ }^{49}$ At the time of the works on the codification, the possibility that divine authority might supplement the consent was contemplated (num divina potestas supplere posit consensum) and the case of sanatio in radice was considered, where the Church validates marriage without either party knowing of this and when this same party is not willing to sanction the marriage..$^{50}$

\section{Definition of Consent}

Can. 1057, $\$ 2$ of CIC/83 is classified as a determination ${ }^{51}$ or definition of matrimonial consent..$^{52} \mathrm{~A}$ methodologically strict analysis allows us to find in this provision a real definition of matrimonial consent, which describes what consent is and unambiguous, which means that whenever consent is mentioned in the code, it is referred to in the same sense as the one stipulated by the contents of the norm. ${ }^{53}$ According to Grzegorz Erlebach, this is a formal definition of matrimonial consent, which does not so much refer to a specific concept belonging to the canon law system, but rather has the reality regulated by this law as its object. ${ }^{54}$ José Maria Serrano Ruiz believes that Can. 1057, $22 C I C / 83$ is not an exhaustive definition of matrimonial consent,

\footnotetext{
48 Cf. Sztafrowski, Podręcznik prawa, 30; Góralski, Małżeństwo kanoniczne, 45; Franciscus, De concordia inter Codices, art. 6, art. 10.

49 Cf. Vlaming - Bender, Praelectiones iuris, 375.

50 Comm. 33/1 (2001) 41.

51 Cf. Góralski, Małżeństwo kanoniczne, 46.

52 Cf. Funghini, "L'escluzione," 282.

53 Cf. Ajdukiewicz, “Definicja," 846-847; "Definicja realna," 60; Kiczuk, “Jednoznaczność," 1052.

54 Cf. Erlebach, "Problem wymiaru," 13.
} 
and additionally there occurs tautology therein. It concerns the phrase: Consensus matrimonialis ... ad constituendum matrimonium. In order to eliminate this error, the author postulates that in the place of the expression matrimonium, a sentence from the definition of marriage should be substituted: quo vir et mulier inter se totius vitae consortium constituunt. ${ }^{55}$

\section{The Nature of Matrimonial Consent}

The legislator showed that the matrimonial consent in Can. 1057, $\$ 2$ CIC/83 as an act of will, as emphasized in the statement consensus matrimonialis est actus voluntatis. ${ }^{56}$ However, it must not be forgotten that the act of human will presupposes prior intellectual knowledge and consent on the part of the reason, because: nihl est volitum nisi praecognitum - nothing is the object of volition unless it was previously known. The prospective spouse's reason must be aware of the voluntary act of granting matrimonial consent. ${ }^{57}$ In the judgment coram Pena of December 10, 2010, we find a clarification of the definition of consent: Consensus autem est actus rationis et voluntatis a nubentibus elicitus, quo iidem mutuam suiipsius donationem in matrimonio perficiunt. ${ }^{58}$ Moreover, matrimonial consent is a human act (actus humanus), since mutual donation and acceptance constitute a conscious, voluntary, and deliberate action by the prospective spouses, which derives from prudent will. ${ }^{59}$ It is also a legal act which produces permanent legal effects. ${ }^{60}$

The internal will of a man and woman, separately, cannot establish marriage understood in accordance with Can. 1055 CIC/83. For this, the conjunction of the two wills of the prospective spouses, which merge into one reality, into a marriage pact is needed. ${ }^{61}$ However, for this to happen, these internal wills need to be manifested. If the internal will is not communicated by the prospective spouses on the externum forum, using words or equivalent signs, it is ineffective. What is required is the materialization of the inner will of a man and woman in a perceptible sign which expresses these wills. ${ }^{62}$ This is confirmed by the maxim: intentio mente retenta, nec parti expressa, nihil in humanis contractibus operatur - the internal intention of the will,

55 Cf. Serrano Ruíz, "L'errore sulla," 169.

56 Cf. Fumagalli Carulli, Intelletto e volontà, 137.

57 Cf. Bánk, Connubia canonica, 329; Michiels, De delictis, 84; Pastuszko, “Świadomość symulacji," 99.

58 Cf. "Dec. coram Pena, 10 dec. 2010," 41.

59 Cf. Góralski, Małżeństwo kanoniczne, 46; Supremum Tribunal Signaturae Apostolicae, "Dioecesis Ultraiecten," 301; Sikorski, "Actus humanus," 144; Stępień, "Akt ludzki," 263-264.

60 Cf. Moneta, "Il Matrimonio," 185; Chiappetta, Il Codice, 266-267; Góralski, Małżeństwo kanoniczne, 45; Góralski, "Rola zgody," 5.

61 Cf. Viladrich, Il consenso matrimoniale, 299.

62 Cf. Viladrich, Il consenso matrimoniale, 300-303. 
which is not expressed externally, plays no role in the contracts between people. ${ }^{63}$ The legislator also adopted in Can. $1101, \$ 1 C I C / 83$ an ordinary presumption whereby the internal consent of the mind is presumed to conform to the words and signs used in celebrating the marriage. This means that the consent expressed externally is a reflection of the inner will of the prospective spouses and there is no dissonance between them. ${ }^{64}$

Moreover, in order to ensure the legal effectiveness of matrimonial consent, it is necessary for the acts of will of a man and woman to be characterized by adhesion, consisting in the adhesion of the will, in the sense of a psychological act, to the legal concept of marital will. During the conveyance of consent, a psychological and legal consolidation of the will of the entities intending to enter into marriage is made. As a result, a marriage contract is created..$^{65}$

\section{Personalistic Concept of the Subject of Matrimonial Consent}

The legislator themselves in Can. 1057, $\$ 2$ CIC/83 redefined the subject of matrimonial consent. During work on the codification at the session of Coetus Studiorum de Matrimonio, committed to updating matrimonial law, on October 24, 1966, a suggestion was made to closely link the definition of the object of the consent with the future definition of marriage: definitio obiecti consensus matrimonialis nequit esse alia ac definitio matrimonii ipsius; ipsum enim matrimonium est obiectum illius consensus, cum actus ab obiecto specificetur - the definition of the object of matrimonial consent cannot be different from the definition of the marriage itself; for marriage itself is subject to that consent, since the act of consent is determined by its object. ${ }^{66}$

In the former Can. $1081 \$ 2 C I C / 17$, the object of matrimonial consent was reduced to ius in corpus, or more precisely, to the exchange of the law of ius in corpus. Such a formulation gave the impression that only the body of the spouses was the object of the consent. ${ }^{67}$ Marriage, however, is more than just a sexually procreative communion, as it covers all levels of the spouses' lives. ${ }^{68}$ The new personalistic treatment of the object of matrimonial consent inscribed in Can. 1057, 22 CIC/83 is a consequence of the definition of marriage ${ }^{69}$ adopted in $C I C / 83$, but also of the sen-

\footnotetext{
63 Cf. Hurtado, Resolutiones morales, 53; Sanchez, Sancto matrimonii, 44.

64 Cf. Pawluk, Prawo Kanoniczne, 154.

65 Cf. Fumagalli Carulli, Intelletto e volontà, 138-139.

66 Cf. Comm. 32/2 (2000) 177; Rybczyk, "Projekt reformy," 201.

67 Cf. Burke, "La «traditio suiipsius»."

68 Cf. Wąsik, "Pojęcie małżeństwa," 196.

69 Cf. Hemperek et al., Komentarz do Kodeksu, 221; Reinhardt, "Entsprechen Konsensanforderung," 70; Góralski et al., Komentarz do Kodeksu, 254; Vela, "De personalismo," 56.
} 
tence of the Apostolic Signatura, coram Staffa, of November 29, 1975, in which we read: Obiectum consensus... declaratur esse coniuges ipsos. ${ }^{70}$ The object of consent in Can. 1057, \$2 CIC/83 includes a man and a woman who, in an irrevocable covenant, give themselves to each other and accept each other for the purpose of creating a marriage. ${ }^{71}$ The man's act of will and the woman's act of will bestow them to each other as a mutual gift and acceptance of each other. ${ }^{72}$ This concept is controversial and criticized because a person cannot give all of themselves to another person, and at best they can convey some of their services and activities. ${ }^{73}$ Attempts are being made to solve this problem. Some canonists, following Card. Pietro Gasparri, distinguish the material object of the matrimonial consent - it is the persons of the parties to the contract who transfer themselves not in a physical, but in a moral sense, analogous to the formal object, which is - taking into account Can. 1057, \$2 CIC/83 and Can. 1055, $\$ 1$ CIC/83 - the communion of the spouses' entire life. ${ }^{74}$ Others create their own concepts. Ryszard Sztychmiler reduces the object of consent to mutual dedication and the transfer of rights to oneself by the prospective spouses, resulting from natural law and the teachings of the Church. ${ }^{75}$ According to Wojciech Góralski, the object of matrimonial consent also includes, apart from ius in personam, the essential attributes of marriage, which, according to Can. $1056 \mathrm{CIC} / 83$ are the unity and indissolubility of marriage ${ }^{76}$ and the whole complex of matters and duties specific to marriage, consisting in the creation of a community for mutual commitment and fulfillment. ${ }^{77}$

During the work on the revision of the Code, postulates emerged, claiming that the subject of matrimonial consent should also include conjugal love. Pope Paul VI made it clear in his address to the Roman Rota on February 9, 1976, that marriage is not legally based on love and therefore does not pertain to the object of consent. ${ }^{78}$ If conjugal love were to be given legal significance and recognized as a component of the object of matrimonial consent, the lack of love would render the marriage nullified. However, there are no objective and sufficient criteria for verifying conjugal love, so in the procedural practice it would not be possible to decide whether a given marriage was validly contracted or not. ${ }^{79}$

\footnotetext{
70 Cf. Supremum Tribunal Signaturae Apostolicae, "Dioecesis Ultraiecten," 306.

71 Cf. Góralski et al., Komentarz do Kodeksu, 254; Góralski, Małżństwo kanoniczne, 46-47; Burke, "La «traditio suiipsius»"”

72 Cf. Viladrich, Il consenso matrimoniale, 299.

73 Cf. Góralski, Małżeństwo kanoniczne, 48.

74 Cf. Hendriks, Diritto matrimoniale, 51; Stawniak, Niemoc płciowa, 327-328.

75 Cf. Sztychmiler, Doktryna Soboru, 363-364.

76 Cf. Góralski et al., Komentarz do Kodeksu, 254.

77 Cf. Góralski, Małżeństwo kanoniczne, 46-47.

78 Cf. Paulus VI, “Allocutio," 204-208.

79 Cf. Sztychmiler, Doktryna Soboru, 373-376.
} 


\section{Summary}

The ecclesiastical legislator introduced a revised norm on matrimonial consent into $\mathrm{CIC} / 83$, inspired by the doctrine of Vatican II on marriage and Christian personalism. Can. 1057 CIC/83 replaced the former Can. 1081 CIC/17. In the new Code, the position of the norm on matrimonial consent was corrected. The former Can. 1081 $C I C / 17$ placed at the beginning of the chapter De consensu matrimoniali, defined consent from the positive side while the following canons mentioning the defects of matrimonial consent described it from the negative side. In $C I C / 83$, the legislator applied a different, more practical solution. Can. 1057 CIC/83 was among the norms forming an introduction to the entire title De matrimonio, next to the definition of marriage and the provision on the essential attributes of marriage. This treatment allowed for the creation of a more orderly and uniform vision of marriage in the code. Moreover, the definition of matrimonial consent in Can. 1057 CIC/83 gained the rank of a real and unambiguous definition in the entire system of canon law.

In the first paragraph of Can. 1057 CIC/83 the legislator repeated verbatim the contents of Can. $1081 \$ 1 \mathrm{CIC/17}$, with a slight change in punctuation. However, he had little room for maneuver here because the principle that matrimonial consent is the efficient cause of marriage - that is, the element that creates a particular marriage - is a declaration of natural law. This rule, read in the context of sources, acquires a fuller, personalistic dimension. It is complemented by another legal principle which states that the matrimonial consent expressed by the prospective spouses cannot be supplemented by any human authority.

The brief formula used in Can. 1057, $\$ 1 C I C / 83$, which states that matrimonial consent is the efficient cause of a specific marriage, carries deeper content. First, it testifies to the fact that this norm adopts the concept of a consensual contract, i.e., of the sufficiency of matrimonial consent for contracting marriage (solus consensus). Secondly, since the canonical marriage of the baptized persons takes on a juridical-religious structure, it indicates that consent simultaneously creates marriage in the contractual and sacramental dimension. This is because the sacramental profile of a Christian marriage is not an addition or supplement to the marriage contract but belongs to the essence of the marital tie. Negating this would lead to the rejection of the institution of marriage according to the teachings of the Church.

The church legislator, taking into account the postulate, developed while working on the codification, that the definition of the subject of matrimonial consent cannot be different than the definition of marriage itself, made far-reaching changes to Can. $1057 \$ 2$ CIC/83, which was adapted to the definition of marriage. In Can. 1081, $\$ 2 C I C / 17$, in line with the tendencies prevailing in canon law studies of the time, the object of matrimonial consent was harmonized with the primary purpose of marriage and was reduced to ius in corpus. Such a concept, however, gave the impression 
that only the spouses' bodies and their sexual-procreative sphere constitute the object of the consent. However, in the light of the teachings of Vatican II, marriage is something more than just a communion of people implemented in the biological and reproductive sphere, because it covers all levels of the spouses' life. Therefore, in Can. 1057, $\$ 2 C I C / 83$, a new, personalistic approach to the subject of matrimonial consent was introduced, centered around the idea of spouses as parties to a contract who transfer themselves in an analogous sense (material object) and the communion of their entire lives, in all its dimensions (formal object). The proposal to include conjugal love as the object of matrimonial consent was rejected, as there are no criteria for its verification. Such a solution would translate into lawsuit practice and impossibility of resolving matrimonial cases.

Translated by Grzegorz Knyś

\section{Bibliography}

\section{Sources}

"Codex Iuris Canonici Pii X Pontificis Maximi iussu digestus Benedicti Papae XV auctoritate promulgatus praefatione, fontium annotatione et indice analityco-alphabetico ab Emo Petro Card. Gasparri auctus," Acta Apostolicae Sedis 9/2 (1917) 1-521 (= CIC/17).

"Codex Iuris Canonici. Auctoritate Ioannis Pauli PP. II promulgatus," Acta Apostolicae Sedis 75/2 (1983) 1-301; English trans.: Code of Canon Law 1983, https://www.vatican.va/archive/ cod-iuris-canonici/cic_index_en.html [access: 9.12.2020] (=CIC/83).

Pontificia Commissio Codici Iuris Canonici Authentice Interpretando, Codex Iuris Canonici auctoritate Ioannis Pauli PP. II promulgatus. Fontium annotatione et indice analytico - alphabetico auctus (Città del Vaticano: Libreria Editrice Vaticana 1989) (= CICFontes/83).

\section{References}

Ajdukiewicz, K., "Definicja," Wielka encyklopedia powszechna PWN (Warszawa: PWN 1963) II, 846-847.

Aubé, H. - de Caparros, E. (dir.), Code de droit canonique bilingue et annoté, 3 ed. (Montreal: Librairie Wilson \& Lafleur 2007);

Bánk, J., Connubia canonica (Roma - Friburgi Br. - Barcinone: Herder 1959).

Boggiano Pico, A., Il matrimonio nel diritto canonico (Torino: Unione Tipografico - Editrice Torinese 1936).

Bonnet, P., Introduzione al consenso matrimoniale canonico (Milano: Giuffrè 1983).

Bonnet, P., "La capacità di intendere e di volere," Diritto matrimoniale canonico. II. Il consenso (eds. P. Bonnet - C. Gullo) (Studi Giuridici 61; Città del Vaticano: Libreria Editrice Vaticana 2003) 35-71.

Burke, C., "La «traditio suiipsius», oggetto del consenso matrimoniale?," C. Burke, L' Oggetto del Consenso Matrimoniale - unanalisi personalistica (Torino: Giappichelli 1997) http:// www.cormacburke.or.ke/node/193 [access: 6.03.2021]. 
Cavana, P., "La condizione," La giurisprudenza della Rota Romana sul consenso matrimoniale (1908-2008) (Studi Giuridici 83; Città del Vaticano: Libreria Editrice Vaticana 2009) 237-258.

Chiappetta, L., Il Codice di Diritto Canonico. Commento giuridico-pastorale. II. Libri III-IV-V-VI, 3 ed. (eds. F. Catozzella - A. Catta - L. Sabbarese) (Bologna: Dehoniane 2011).

Coetus Studiorum “de Matrimonio," "Sessio I," Communicationes 32/2 (2000) 175-227 (= Comm.). Coetus Studiorum “de Matrimonio," "Sessio IV," Communicationes 33/1 (2001) 32-61 (= Comm.). Coetus Studiorum de Iure Matrimoniali, "Schematis cann. 242-264," Communicationes 9/1 (1977) 117-146 (= Comm.).

Czapla, M., "Pojęcie «matrimoniale foedus» w kan. 1055, \$1 KPK," Ius Matrimoniale 5/11 (2000) 23-41.

“Decisio coram Pena, 10 decembris 2010, Romanae Rotae Tribunal," Decisones seu Sententiae 102 (2017) 409-418.

"Definicja realna," Mały słownik terminów i pojęć filozoficznych dla studiujących filozofię chrześcijańską (eds. A. Podsiad - Z. Więckowski) (Warszawa: Instytut Wydawniczy PAX 1983) 60.

Denzinger, H. - Schönmetzer, A.A., Enchiridion symbolorum definitionum et declarationum de rebus fidei et morum, 36 ed. (Barcinone - Friburgi Br. - Romae: Herder 1976) (= DS).

Duda, J., Katolícke manželské právo (Ružomberok: Pedagogická Fakulta Katolíckej Univerzity v Ružomberku 2007).

Erlebach, G., "Problem wymiaru antropologicznego i prawnego w rozumieniu zgody małżeńskiej," Ius Matrimoniale 10/4 (1999) 7-28.

Fernández Castaño, J.M., Legislación matrimonial de la Iglesia (Salamanca: San Esteban 1994).

Florczyk, M. - Misztal, W., "Wprowadzenie do Konstytucji duszpasterskiej o Kościele w świecie współczesnym," Sobór Watykański II. Konstytucje Dekrety Deklaracje. Tekst polski. Nowe tłumaczenie (Poznań: Pallottinum 2002) 511-525.

Franciscus, Literrae Apostolicae Motu proprio datae De concordia inter Codices. Quibus nonnullae normae Codicis Iuris Canonici immutantur, diei 31 Mai 2016, http://w2.vatican.va/content/francesco/la/motu_proprio/documents/papa-francesco-motu_proprio_20160531_ de-concordia-inter-codices.html [access: 9.12.2020].

Fumagalli Carulli, O., Intelletto e volontà nel consenso matrimoniale in diritto canonico (Milno: Università Cattolica del Santa Cuore 1974).

Funghini, R., "L'escluzione del bonum fidei," Diritto matrimoniale canonico. II. Il consenso (eds. P. Bonnet - C. Gullo) (Studi Giuridici 61; Città del Vaticano: Libreria Editrice Vaticana 2003) 279-285.

Gajda, P.M., Prawo małżeńskie Kościoła katolickiego (Tarnów: Biblos 2013).

Gasparri, P., Tractatus canonicus de matrimonio (editio nova ad mentem C.I.C.) ([Città del Vaticano]: Typis Polyglottis Vaticanis 1932) II.

Gerosa, L., Prawo Kościoła (ed. L. Balter; trans. I. Pękalski) (Poznań: Pallottinum 1999).

Giacchi, O., Il consenso nel matrimonio canonico, 3 ed. (Miano: Giuffrè 1968).

Góralski, W., "Rola zgody stron w powstawaniu małżeństwa, jej natura i przedmiot (kan. 1057 § 1-2 KPK)," Ius matrimoniale. Ze studiów nad kościelnym prawem mał̇̇eńskim (Lublin: Wąbrzeskie Zakłady Graficzne 1991) II, 5-12. 


\section{WOJCIECH WASIK}

Góralski, W. et al., Komentarz do Kodeksu Prawa Kanonicznego. III/2. Księga IV. Uświęcające zadanie Kościoła. Część I. Sakramenty. Część II. Pozostałe akty kultu Bożego. Część III. Miejsca i czasy święte (Poznań: Pallottinum 2011).

Góralski, W., Małżeństwo kanoniczne (Warszawa: Lex Nexis 2011).

Hemperek, P. et al., Komentarz do Kodeksu Prawa Kanonicznego. III. Ksiega III. Nauczycielskie zadanie Kościoła. Księga IV. Uświęcające zadanie Kościoła (Lublin: RW KUL 1986).

Hendriks, J., Diritto matrimoniale. Commento ai canoni 1055-1165 del Codice di diritto canonico (Milano: Ancora 1999).

Hurtado, T., Resolutiones morales [...] Pars prior [...] (Lugundi: Anisson 1651).

Kahler, H., Absentia consensus. Der fehlende Mindestwille zur Ehe als Ehenichtigkeitsgrund (Frankfurt: Lang 1999).

Kiczuk, S., "Jednoznaczność," Encyklopedia katolicka (eds. S. Wielgus et al.) (Lublin: TN KUL 1997) VII, 1152.

Lüdicke, K., "Kryteria rozróżnienia form wadliwej zgody małżeńskiej w prawie kanonicznym," Przymierze małżeńskie (eds. W. Góralski - R. Sztychmiler) (Lublin: TN KUL 1993) 61-73.

Majer, P. (ed.), Kodeks Prawa Kanonicznego. Komentarz (Kraków: Wolters Kluwer 2011).

Michiels, G., De delictis et poenis. Commentarius libri V Codicis Juris Canonici. I. De delictis. Canones 2195-2213 (Lublin: Universitsas Catholica - Brasschaat: De Bièvre 1934).

Mommsen, T. (ed.), "Digesta," Corpus Iuris Civilis, Institutiones recognovit Paulus Krueger. Digesta recognovit Theodorus Mommsen, 16 ed. (Berolini: Apud Weidmanos 1954) I (=D).

Moneta, P., "Il Matrimonio (can. 1055-1165)," Il Diritto nel mistero della Chiesa. III. La funzione di sanctificare della Chiesa. I beni temporali della Chiesa. Le sanzioni - I procesi Chiesa e communità politica (ed. Gruppo Italiano Docenti di Diritto Canonico) (Roma: Pontificia Università Lateranense 1992) 165-315.

Mosiek, U., Kirchliches Eherecht unter Berücksichtigung der nachkonziliaren Rechtslage, 2 ed. (Freiburg: Rombach 1972).

Navarrete, U., "Mutationes et praevisae innovationes in iure matrimoniali," Prawo Kanoniczne 15/1-2 (1972) 3-17.

Navarrete, U., "Amor coniugalis et consensus matrimonialis: quid Paulus VI in allocutione ad praelatos S. R. Rotae 9 feb. 1976 doceat?," Periodica de re morali canonica liturgica 65 (1976) 619-632.

Pastuszko, M., "Świadomość symulacji u całkowicie symulującego zawarcie małżeństwa," Prawo Kanoniczne 17/3-4 (1974) 97-106.

Pastwa, A., Istotne elementy małżeństwa w nurcie odnowy personalistycznej (Katowice: Wydawnictwo Uniwersytetu Śląskiego 2007).

Paulus VI, "Allocutio ad Pralatos, Auditores, et Officiales Tribunalis Sacrae Romanae Rotae de die 28 februarii 1976," Acta Apostolicae Sedis 68 (1976) 204-208.

Pawluk, T., Prawo Kanoniczne według Kodeksu Jana Pawła II. III. Prawo małżeńskie (Olsztyn: Warmińskie Wydawnictwo Diecezjalne 1996).

Pesch, O., Ehe im Blick des Glaubens, http://www.weinzweb.de/ohp/peschehe.pdf [access: 9.12.2020].

Полдников, Д., Формирование учения о договоре в правовой науке западной Европы (XIIXVI вв.) (Dуs. Высшая Школа Экономики: Москва 2016). 
Primetshofer, B., "Der Ehekonsens," Handbuch des katholischen Kirchenrechts (eds. J. Listl H. Müller - H. Schmitz) (Regensburg: Pustet) 765-782.

Reinhardt, H., "Nowe tendencje orzecznictwa kościelnego w zakresie zgody małżeńskiej ze szczególnym uwzględnieniem orzeczeń oficjalatu z Münster," Przymierze małżeńskie (eds. W. Góralski - R. Sztychmiler) (Lublin: TN KUL 1993) 97-113.

Reinhardt, H., "Entsprechen Konsensanforderung (c. 1057 CIC) und Konsensmängel (cc. 1095-1003 CIC) einander?," De processibus matrimonialibus. Fachzeitschrift zu Fragen des kanonischen Ehe- und Prozeßrechtes (eds. E. von Güthoff - K. Selge) (Leipzig: Benno 1994) II, 69-87.

Rhode, U., Vorlesung “Das kirchliche Eherecht," https://www.ulrichrhode.de/ehe/e-skriptum.pdf [access: 27.11.2020].

Robleda, O., "Causa efficiens matrimonii iuxta const. «Gaudium et spes» Conc. Vaticani II," W. Bertrams et al., De matrimonio coniectanea (Roma: Universtà Gregoriana Editrice 1970) 654-673.

Rybczyk, J., “Projekt reformy prawa małżeńskiego (część I - kanony: 1012-1034)," Prawo Kanoniczne 20/1-2 (1977) 201-211.

Sanchez, T., Sancto matrimonii sacramento disputationum libri tres [...] (Lugundi: Anisson 1669) I.

Sarmiento, A., Małżeństwo chrześcijańskie. Podręcznik teologii małżeństwa i rodziny (ed. K. Gryz; trans. P. Rak) (Kraków: Wydawnictwo M 2002).

Serrano Ruiz, J.M. et al., Matrimonio canonico fra tradizione e rinnovamento (Bologna: Edizioni Dehoniane Bologna 1985).

Serrano Ruíz, J.M., "Lerrore sulla qualità «directe et principaliter intenta» nel consenso matrimoniale," Diritto matrimoniale canonico. II. Il consenso (eds. P. Bonnet - C. Gullo) (Studi Giuridici 61; Città del Vaticano: Libreria Editrice Vaticana 2003) 163-175.

Sikorski, T., "Actus humanus," Studia Theologica Varsaviensia 11/1 (1973) 141-159.

Skrzydlewski, W., "Castii Connubii,” Encyklopedia katolicka (eds. L. Gryglewicz - R. Łukaszyk - Z. Sułowski) (Lublin: TN KUL 1995) II, 1359-1360.

Stasiak, M., "Teologiczne podstawy nowego Kodeksu Prawa Kanonicznego według konstytucji Sacrae disciplinae leges," Roczniki Teologiczno Kanoniczne 31/5 (1984) 83-91.

Stawniak, H., Niemoc płciowa jako przeszkoda do małżeństwa. Ewolucja czy zmiana koncepcji? (Warszawa: Wydawnictwo UKSW 2000).

Stępień, A., "Akt ludzki. I. Fenomentologia aktu ludzkiego," Encyklopedia katolicka (eds. F. Gryglewicz - R. Łukaszyk - Z. Sułowski) (Lublin: TN KUL 1995) I, 263-264;

Supremum Tribunal Signaturae Apostolicae, "Dioecesis Ultraiecten. Nullitatis matrimonii coram Staffa diei 29 novembris 1975," Periodica de re morali canonica liturgica 66/1-2 (1977) 297-325.

Sztafrowski, E., Podręcznik prawa kanonicznego (Warszawa: ATK 1986) IV.

Sztychmiler, R., Doktryna Soboru Watykańskiego II o celach małżeństwa i jej recepcja w kodeksie prawa kanonicznego z roku 1983 (Lublin: TN KUL 1993).

Urbanowska-Wójcińska, D., “Zgoda małżeńska w kanonicznym systemie prawnym a oświadczenie o zawarciu małżeństwa w prawie polskim rodzinnym," Ius Matrimoniale 25 (2014) $57-75$. 
Vela, L., "De personalismo in Iure matrimoniali novi Codicis," Periodica de re morali canonica liturgica 79/1-2 (1990) 37-67.

Viladrich, P., Il consenso matrimoniale. Techniche di qualificazione e di esegesi cause canoniche di nullità (cc. 1095-1107 CIC) (Milano: Giuffrè 2001).

Vitali, E. - Berlingò, S., Il matrimonio canonico (Milano: Giuffrè 2007).

Vlaming, T. - Bender, L., Praelectiones iuris matrimonii ad normam Codicis Iuris Canonici (Bussum: Brand 1950).

Wąsik, W., "Symulacja zgody małżeńskiej jako przyczyna nieważności małżeństwa w prawie Kościoła łacińskiego," Kieleckie Studia Teologiczne 12 (2013) 215-253.

Wąsik, W., "Pojęcie małżeństwa w kan. 1055 KPK 1983," Kieleckie Studia Teologiczne 18 (2019) 185-206.

Zubert, B., "Consensus sacramentalis facit nuptias?," Przymierze małżeńskie (eds. W. Góralski - R. Sztychmiler) (Lublin: TN KUL 1993) 7-30.

Żurowski, M., Kanoniczne prawo małżeńskie Kościoła katolickiego (Katowice: Księgarnia św. Jacka 1987). 